УДК 130.2:34:7.03’06

DOI: https://doi.org/10.21564/2075-7190.42.170729

Meliakova Yuliia Vasylivna, $\mathrm{PhD}$ in Philosophy, Associate Professor, Associate Professor of Philosophy Department, Yaroslav Mudryi National Law University, Kharkiv, Ukraine e-mail: melyak770828@gmail.com ORCID ID: 0000-0001-6699-8078

Zhdanenko Svitlana Borysivna, $\mathrm{PhD}$ in Philosophy, Associate Professor, Associate Professor of Philosophy Department, Yaroslav Mudryi National Law University, Kharkiv, Ukraine e-mail: svetlana.zdanenko@gmail.com

ORCID ID: 0000-0001-6276-8275

Egert Vladyslav Olegovych, student of Faculty of International Law, Yaroslav Mudryi National Law University, Kharkiv, Ukraine e-mail: egvlad97@gmail.com

\title{
PERFORMANCE IN THE METHODOLOGY OF PHILOSOPHY OF LAW
}

With the help of performance as a structure-forming device and a method of understanding being, the ontological problem of the presence of law can be solved. The reality of law, which is constructed according to the interactive model of performance, can not only discover its initial meaning or receive a new one, but also have an effective impact on the participating subjects, involving them in a single horizon of law being.

Keywords: dynamism of law, presence, performative, performance, interact, physicality of law.

Problem setting. In the simulative space of the modern world, we face a lack of reality. This problem has not bypassed the ontology of law. It is precisely the metamorphosis of being and modality of law that condition today"s search for the new in philosophical and legal methodology. Superficial meanings and the changeable significance of law make it possible to speak of its formal presence rather than the real embodiment. The reality of law manifests itself mainly in the effectiveness of the impact on specific events. Influence and effectiveness are the most relevant criteria for the essence of law, like for any other thing in the modern trends of visualization and virtualization. 
The realities are steadily multiplied, as are the ways of the subject being in them. The effectiveness of law in this multilayered reality largely depends on the choice of the method of its reading, on the method of expression and the set of signs and symbols of legal reality. The dynamic context of various kinds of narrative and material nomological forms, constructed in the technique of performance, is almost able to recreate the body of law. That is, the very meaning of law acquires the signs of physicality, in other words, it is real to the extent that it is able to influence modern reality, thereby ensuring the presence of law here and now.

Analysis of recent research and publications. The philosophical tradition of the dynamic nature of law is being developed by I. Chestnov, V. Chetvernin, A. Polyakov, S. Maksimov, A. Stovba and other researchers. Significant experience in this area belongs to the European representatives of the communicative paradigm. J. Austin, in the framework of communicative philosophy, developed the theory of performative discourse. According to this theory, speech acts that have the character of order, demand, promise, or oath are no longer statements, but actions. H. Hart applied the theory of performative utterances to the legal texts and discourses. Among the Russian scientists, V. Ogleznev, Y. Griaznova, Y. Kupchenko deal with the problem of legal performative. Polish researcher E. Domanska notes that performativity is becoming a new modern paradigm of cognition and methodology of science. Modern postmodern philosophy has once again actualized a discourse as a practice of interactive communication and the so-called perpendicular human existence in virtual reality. Popularization of the role of language and discourse in the meaning of "existential therapy" is called the new cosmology and the magic of postmodern of (S. Frunza, L. Marinoff, M. R.-M. Shapiro, S. Ivik).

The technique of performance in art, its expressive possibilities are the themes of research by S. Kornev, P. Weibel, S. Žižek, C. Malabou. Performance as an ontological space of presence production and a special technique of provocation of physicality is the subject of research by V. Rybakov, H. Gumbrecht. At the same time, the question about the possibility of applying the technique of performance into the practice of reproducing justice remains open. In this study, performance is viewed as a special way of law being. The law-performance equips the presence of the subject in it.

The goal formulation. Today the performance acts as the dynamic model of interactive law, and guarantees the reality of law and its unconditional influence on the consciousness and actions of the subjects involved in it. The performance of law is formed in the dynamics of the attributes of its verbal structures (texts, material evidence, facts, testimonies, actions, procedures, normative statements) and at the same time it itself acts as a new relevant technique of dynamism of law. It is the consideration of performance as a qualitatively new form of law being, as well as the analysis of its expressive possibilities, is the goal of this study. 
The main material presentation. Philosophy that performs the methodological function in relation to the legal sciences can be considered, without exaggeration, a source of new paradigm assumptions in the sphere of representation and scientific cognition. The recent semiotic and cognitive innovations in science were driven by a communicative paradigm that revealed the true existence of the objects and things in the symbolic space of text and language. However, if only yesterday, the Humanities called for the metaphor of the world as a text, today, so-called new humanitarian knowledge, in particular, interdisciplinary cultural studies of the European and American scientists, call for the metaphor of the world as a number of performative acts, the participants of which are the subjects of cognition themselves.

Performativity can rightly be considered as a new methodological paradigm. The term "performance" has become ubiquitous in the modern socio-humanitarian knowledge. The concept of performative textualism became relevant even within the framework of the communicative paradigm, in the analytical philosophy of J. Austin. J. Austin called performative utterances those ones which are the implementation of certain actions or constitute certain consequences for the speaker (for example, promises, requests, oaths, orders, agreements) [1, p. 66].

The effect of performative, according to J. Austin, is realized in the speech act itself, that is, the performative utterance relates to the situation, which it itself provokes, ordering, managing, demanding, blaming, etc. The speech act, according to $\mathrm{J}$. Austin is such a process of communication of individuals, in which, in addition to expressing meaningful statements (locutions), there is an interactive influence of communicants on each other, that is an interactional effect (illocutions and perlocutions [2]), achieved through speaking as an act of promise, intimidation or obligation. Such a speech act is a performative. Any performative, thus, is a choice made by the speaker in a communication situation [2, p. 105].

Legal performative can be defined as a speech act produced in the framework of a specific legal procedure for the implementation of socially significant legal actions. Legal relations always contain performative verbs of the type "I promise", "I demand", "I undertake". Various kinds of legal activity are, at the same time, a certain performative activity, that is, the dramatization of certain relationships with the help of language: for example, legal advice, participation in a court session, aquital, accusation, interpretation, promise, oath, debenture, contract or marriage registration, etc. Thus, for example, stipulation in Roman law as a verbal contract for an obligation between a creditor and a debtor, which secured their rights and obligations for both parties to the contract, evidences to the traditional cult of the word and a kind of ritual in legal relations, which becomes possible thanks to the performative utterances.

Performative as a ritual is of a particular importance in religious legal families in ideational legal systems, as P. Sorokin claims [3, p. 387]. The code of laws there 
is considered as given by God; therefore the punishments are also of a ritual nature: cursing, giving to hell, excommunication from the church, etc. In the modern European law, the operative part (operative) of a legal document itself is the fulfillment by the subjects of a statutory action at the moment when they consciously express their will, fixing it in a performative text. In general, legal performatives play the role of actions made in the sphere of subject-object relations, in which there are the authoritative power carriers. In this regard, the Russian philologist Y. Kupchenko states that performative utterances of the legal nature, with an imperative, normative-setting sense, generate larger contents [1, p.68].

However, the performatative aspect in the methodology of legal science is not exhausted by the infusions of J. Austin"s analytical philosophy and its subsequent developments by H. Hart in the conception of "legal order" [4]. The theory of performability certainly deserves a more in-depth study within the framework of modern philosophy and methodology of law. At the same time, two concepts should be separated, which are "performative" and "performance", in accordance with their informative features. Thus, "performative" is used in the meaning of "performative text" as a special type of text actualized in a communication situation and is primarily an action: firstly, a communicative action, and secondly, an act of self-representation of the speakers [5]. Performative acts as an alternative to a descriptive text. This, in particular, is a consequence of the fact that the communicative paradigm is characterized by the principle of demonstrativeness, or by self-representation by communicating their individuality and their own will. It is with the search for the new forms of representation that the latest developments in the methodology of the social sciences and Humanities are connected.

Performance, in its turn, unlike performative, is the concept that is a characteristic of ontological discourse in the art of postmodernism. The practice of performance is associated mainly with the épatage provocations of physicality, that is, the attempts of the artists to arrange an all-round "presence" in their works of all kinds of objects and bodies, namely, nature, in particular, their own body, as well as the body of the viewer. Performative changes in visual aesthetics occur in parallel with the rethinking of the concept of the body as such and the emergence of the phenomenon of physicality in philosophy (the so-called postmodern crisis of identity in Europe in the 1970s). It is precisely the problem of physicality that dictates such areas as philosophical schizoanalysis (G. Deleuze, G. Bataille), the problem of understanding reality and creativity, various simulation practices. Artistic performance is especially provocative. This is the essence of the practice of engaging subjects on both sides of a ramp (screen, canvas) into an abstract situation.

Postmodern philosophy of communication offers a new look at physicality [6]. When communication and "philosophical consulting" evoke existential desires, 
passions and versatile transformations of a person, then the body itself acts as a language, and communication as a therapeutic method of spiritual healing [7]. Virtual communication, similar in its technique to performance, provides a transhuman state that raises the problem of the identity of both people and narratives. Thus, S. Ivik discusses the philosophical identity of the European narratives, which formed the ideas of justice, truth, cooperation in Europe; examines the fundamental narratives of the European heritage in the field of law and culture, which have laid the values of the rule of law, tolerance, equality and pluralism. As a result, philosophical identity is defined by the author as an open process, along with the designated values, which are continuously reinterpreted [8].

Having marked the dynamism of narratives, contexts, identities and values, let us return to the evolution of physicality. The problem of physicality is connected with the frank disappearance of the boundary between the inner and the outer, between the spirit and body, the world of the innermost and social role reality. In the context of performance, an artist (author) either becomes a work of art himself or acts as a social commentator. A spectator is sure to become an accomplice of a provocative event, unique, and spontaneous. The purpose of the performative activity of any of the participants of the action is not entertainment or recreation, but self-cognition. The reality that has been deconstructed by performance once again acquires its physicality due to the active position of the subject-participant. The performance is short-living, therefore the effect of the thickened presence provoked by it quickly dissipates. Yet it is a practice of experiencing, rather than contemplation, a format for going beyond the horizon of meanings. Without guaranteeing the existence of legal reality, performance nevertheless ensures the presence or virtual being in it of participants in a legal action, as well as their experience of both justice and injustice of life.

The main problem of performance as an understanding being is the problem of experience. The instant presence, the lack of inheritance does not allow us to speak of the performative experience in the meaning of a certain behavioral tradition. The performance focuses on the fact that a certain life (or legal) situation can have different options of development, as well as any interaction between people.

Ukrainian art theorist L. Komarnitskaya, conducting an analysis of the genesis, structure and significance of artistic performance, concludes that any visualized situation, including four basic elements: time, place, body of the artist, as well as the relationship of the artist and the audience can be attributed to the performance $[9$, p. 135]. If the performance is viewed not in the narrow sense as a live performance with signs of a theatrical acting, but in a broad sense as an episode of everyday practice of social life, manifested in rituals, festivals, parades, celebrations and other similar events $[10$, p. 227], then nothing contradicts defining as the "performance", also the legal situations in which the law is realized. 
The question arises: to what extent in the legal performance are the body of its author and the relationship of the author with the recipient represented - those to whom the authorities" initiatives and orders are directed? Experience shows that legal relations are not always performance. Events of legislative influence may well have a verbal form, being documented in orders, notices, applications, visas and agreements. The physicality of the participants themselves remains outside the framework of the legal situation. Perhaps, therefore, from the point of view of communicative methodology, the image of law is associated primarily with the performative, but not with the performance. At the same time J. Austin himself claims that with the help of words we not only describe, but also create reality. In turn, E. Domanska also believes that performativity can be defined as a belief that language not only represents reality, but also changes it, and certain phenomena (events) exist only as long as they are performatively repeated [10].

Thus, the main thing is that performative and performance together can give to the understanding of law and legal science - this is a provocation of the presence of the participants of legal reality and the recreation with their help of the legal action, in other words, of the physicality of law. If the legal significance of the performative semantics is already sufficiently substantiated and studied, then the significance and methodological function of the artistic model of performance for the legal science has yet to be studied. Such an initiative has grounds, since at present all areas of knowledge, as well as cultures and arts in the trend of total visualization and virtualization, are desperately fighting for "presence" and its guarantees.

Today, all technical sciences and Humanities methodological searches are directed to the "production of presence". There is no exception for law in its paradigm of dynamism. Thus, H. Gumbrecht characterizes this tendency as a new look at the practice of Humanities, aimed at rehabilitating the effects of sensual and physical presence, the disregard for which has so far made our experience of perception and understanding of culture incomplete [11]. At the same time "presence" is designated by him not as temporary, but as a spatial relation to the world and its objects; "production" of "presence" - as "moving forward" in space, an intensifying effect on a person and his consciousness. Sensual, bodily influence, therefore, acts as the opposite and alternative to meaning - like what we indue the thing and what we interpret in it with the help of symbols.

If the goal of performance as such is to get rid of comments, then the goal of performance as a method of law is to rid the legal sciences of excessive semantic stability and dictate of values, that is, stereotypes, tendentiousness, and engagement. Legal language and text should be in the service for the event, thing and body, and 
not vice versa. This, perhaps, is the task of methodological developments in the field of modern philosophy of law as a practical branch of philosophy.

Conclusions. Thus, performance is called upon to convey the transformative, agile nature of modern legal reality. It is able to demonstrate all the wealth of meanings, forms and modes of law, to manifest its very ontological presence in a specific legal act of communication, but outside the text itself, involving the entire horizon of objects, phenomena, actions and events of a legal nature in a vertical polylog. Just like software visualization technologies make real what is not real, so performance as a technique of presence can expand the possibilities and effectiveness of law, contribute to its flexibility and influence.

\section{ЛIТЕРАТУРА}

1. Купченко Ю. А. Перформативные формулы как генераторы более крупных контентов (на материале юридического дискурса). Критика и семиотика. 2013. № 1 (18). С. 65-72.

2. Остин Дж. Л. Как совершать действия при помощи слов. Избранное / пер. с англ. Л. Б. Макеевой, В. П. Руднева. Москва: Идея-Пресс: Дом интеллект. кн., 1999. $332 \mathrm{c}$.

3. Сорокин П. А. Социокультурная динамика. Москва: Директ-Медиа, 2007. 334 с.

4. Харт Х. Л. А. Концепція права. URL: http://twirpx.com/file/1257455 (дата звернення: 10.01.2018).

5. Грязнова Ю. Б. Анализ перформативного текста (П. Фейерабенд против методологического принуждения). URL: http://sbiblio.com/biblio/archive/grjasnova_ analis/2004 (дата звернення: 10.03.2017).

6. Frunza S. Aurel Codoban - an Existential stylist: From Desire to Love as Communication Instrument. Meta-Research in Hermeneutics Phenomenology and Practical Philosophy. 2018. Vol. 10, Issue 2. P. 568-585.

7. Shapiro M. R.-M. Abracadabra! Postmodern Therapeutic Methods: Language as a Neomagical Tool. Journal for the Study of Religions and Ideologies. 2018. Vol. 17, Issue 49. P. 3-17.

8. Ivic S. European Philosophical Identity Narratives. Cultura-International Journal of Philisophy of culture and axiology. 2018. Vol. 15, Issue 1. P. 125-145.

9. Комарницкая Л. Онтологическая проблематика в искусстве перформанса. Сучасне мистеитво. 2015. Вип. 11. С. 133-145.

10. Доманска Э. Перформативный поворот в современном гуманитарном знании. Способы постижения прошлого. Методология и теория исторической науки / сокр. пер. с англ. М. Кукарцевой; отв. ред М. А. Кукарцева. Москва: «Канон+» РООИ «Реабилитация», 2011. С. 226-235.

11. Гумбрехт Х. У. Производство присутствия: Чего не может передать значение. Москва: Новое лит. обозрение, 2006. 184 c. URL: http://history-library.com/index. php (дата звернення: 11.01.2018). 
12. Остин Дж. Л. Слово как действие. Новое в зарубежной лингвистике / под ред. Б. Ю. Городецкого. Вып. 17: Теория речевых актов. Москва: Прогресс, 1986. C. $22-129$.

13. Грязнова Ю. Б. Перформативные тексты в методологии науки: автореф. дис. ... канд. филос. наук. Москва, 1998. URL: http://refdb.ru/look/3112771.html (дата звернення: 21.11.2017).

\section{REFERENCES}

1. Kupchenko Ju. A. (2013). Performativnye formuly kak generatory bolee krupnyh kontentov (na materiale juridicheskogo diskursa). Kritika i semiotika-Criticism and Semiotics. 1 (18). 65-72 [in Russian].

2. Ostin Dzh. L. (1999). Kak sovershat' dejstvija pri pomoshhi slov. Izbrannoe Moskva: Ideja-Press. Dom intellektual'noj knigi [in Russian].

3. Sorokin P. A. (2007). Sociokul'turnaja dinamika. Moskva: Direkt-Media [in Russian].

4. Hart X. L. A. Koncepciya prava. URL: http://twirpx.com/file/1257455 [in Ukrainian].

5. Grjaznova Ju. B. Analiz performativnogo teksta (P. Fejerabend protiv metodologicheskogo prinuzhdenija). URL: http://sbiblio.com/biblio/archive/grjasnova analis/2004 [in Russian].

6. Frunza S. Aurel Codoban - an Existential stylist: From Desire to Love as Communication Instrument. Meta-Research in Hermeneutics Phenomenology and Practical Philosophy. 2018. Vol. 10. Issue 2. P. 568-585 [in English].

7. Shapiro M. R.-M. Abracadabra! Postmodern Therapeutic Methods: Language as a Neomagical Tool. Journal for the Study of Religions and Ideologies. 2018. Vol. 17. Issue 49. P. 3-17 [in English].

8. Ivic S. European Philosophical Identity Narratives. Cultura-International Journal of Philisophy of culture and axiology. 2018. Vol. 15. Issue 1. P. 125-145 [in English].

9. Komarnickaja L. (2015). Ontologicheskaja problematika $\mathrm{v}$ iskusstve performansa [Ontological problems in the art of performance]. Suchasne my'stecztvo-Modern Art. issue 11. 133-145 [in Ukrainian].

10. Domanska Je. (2011). Performativnyj povorot v sovremennom gumanitarnom znanii. Sposoby postizhenija proshlogo. Metodologija i teorija istoricheskoj nauki-Ways of comprehending the past Methodology and theory of historical science. M. A. Kukarceva (Ed). Moskva: «Kanon+» ROOI «Reabilitacija». 226-235 [in Russian].

11. Gumbreht H. U. (2006). Proizvodstvo prisutstvija: Chego ne mozhet peredat' znachenie. URL: http://history-library.com/index.php [in Russian].

12. Ostin, Dzh.L. (1986). Slovo kak dejstvie [Word as action]. Novoe v zarubezhnoj lingvistike - New in foreign linguistics. issue 17: Teorija rechevyh aktov. Moskva: Progress. 22-129 [in Russian].

13. Grjaznova, Ju.B. (1998). Performativnye teksty v metodologii nauki. Extendded abstract of candidate's thesis. Moskva. URL: http://refdb.ru/look/3112771.html [in Russian]. 
Мелякова Юлія Василівна, кандидат філософських наук, доцент, доцент кафедри філософії Національного юридичного університету імені Ярослава Мудрого, м. Харків, Україна

Жданенко Світлана Борисівна, кандидат філософських наук, доцент, доцент кафедри філософії Національного юридичного університету імені Ярослава Мудрого, м. Харків, Україна

Eгерт Владислав Олегович, студент факультету міжнародного права, Національного юридичного університету імені Ярослава Мудрого, м. Харків, Україна

\section{ПЕРФОРМАНС У МЕТОДОЛОГІЇ ФІЛОСОФІЇ ПРАВА}

Постановка проблеми. Сучасний спосіб буття права $і$ людини в праві змушують шукати нові методи їх розуміння. При цььому сенс права і сила його впливу безпосередньо залежать від онтології присутності людини в праві. У значенні простору такої присутності виступає перформанс. Він стає можсливим через деконструкцію символічних правових структур (норм, правових рімень, прочедур, предметів, прочесуальних дій, подій, договорів, віртуальних образів і т. д.). Саме перформанс може вплинути на суб'єкта права, зробити його креативним учасником реальності права і гарантувати рефлексію ним правових смислів.

Аналіз останніх досліджень і публікацій. Філософську традицію динамічної природи права розвивають I. Честнов, В. Четвернін, А. Поляков, С. Максимов, О. Стовба й інші російські та украӥнські філософи. Значний досвід у иій галузі належить європейським представникам комунікативної парадигми. Дж. Остін у рамках комунікативної філософії розвинув теорію перформативного дискурсу. Відповідно до иієї теорії мовні акти, які мають характер наказу, вимоги або клятви, є вже не висловлюваннями, а діями. Х. Харт застосував теорію перформативних висловлювань до юридичних текстів і дискурсів. Серед російських учених проблемою юридичного перформативу займаються В. Оглєзнєв, Ю. Грязнова, Ю. Купченко.

Польська вчена Е. Доманська зазначає, що перформативність стає новою сучасною парадигмою пізнання $і$ методологї науки. Техніка перформансу в мистецтві, його зображувальні можливості є тематикою досліджень С. Корнєва, П. Вайбеля, С. Жижека, К. Малабу. Перформанс як онтологічний простір виробниитва присутності й особлива техніка провокаиії тілесності 
речей є предметом досліджень В. Рибакова, Х. Гумбрехта. При цььому питання про можливість застосування тактики перформансу в практиці відтворення справедливості залишається відкритим. У даному дослідженні перформанс розглядається як особливий спосіб буття права. Право-перформанс облаштовує присутність у ньому суб'єкта.

Формулювання цілей. Метою дослідження є аналіз правової реальності у форматі перформансу, який слугує оригінальною тактикою актуалізації права.

Виклад основного матеріалу. Якщо комунікативна теорія права вбачала дієвість права в мовних перформативних структурах, то останні методологічні досліди доводять застосування художньої практики перформансу в області буття і розуміння права. Текст як форма буття не вичерпує сутності права. Багатошарова, самоорганізована структура права потребує більш складних, ніж репрезентація, систем вираження. Такою системою визнаний перформанс. Він провокує все нові й нові можливості права, форми його буття.

Мета перформансу в сучасній філософії та мистецтві - позбутися коментарів. Мета перформансу як методу права - позбавити право надмірної семантичної стійкості й диктату значень. Мова і текст права повинні бути на службі у подї, речі і тіла, а не навпаки. На перший погляд заміщення юридичного твердження або вироку відкритою подією, а також заміна відстороненого арбітра-юриста учасником, який переживає иүю подію, роблять правозастосовну практику дуже далекою від юридичної науки і правової істини. Однак відтворена подія життя найближча до того, щуо правові науки називають справедливістю. Тому ступінь присутності права у відтвореній ситуачї має визначатися зовсім не шляхом інтерпретаџії $і$ накладання правових міфів (норм і прецедентів). Така жива справедливість не може бути кимось установлена. У перформансі справжня справедливість актуалізується із самої подї у форматі відкритої присутності.

Новий онтологічний модус права виступає як чистий перформанс своӥх учасників - автора і глядача. Він породжує несподівану, але справжню справедливість, яку неможливо закріпити, не позбавивши ії сенсу. Нове й нове перезавантаження ситуачії за допомогою перформансу здатне множити правову справедливість у ї̈ перформативній тілесності. Водночас правові вироки, рішення, норми і тлумачення, що заклякли у своїх значеннях, містять право формально, однак все далі віддаляються від його реальної присутності фактично.

Висновки. Таким чином, тактика перформансу дозволяє продемонструвати все багатство форм, модусів і смислів права, досягти справжньої присутності суб'єкта в праві через конкретний юридичний акт. Якщо комуні- 
кація вже визнана буттям, дискурс - низкою подій, а перформативне висловлювання - дією, в такому випадку вихід за межі тексту і мови - в різноплановий симбіоз символічних горизонтів, тобто перформанс, означає принщипово новий спосіб буття права, адекватний сучасній реальності.

Ключові слова: динамізм права, присутність, перформатив, перформанс, інтеракт, тілесність права.

Мелякова Юлия Васильевна, кандидат философских наук, доцент, доцент кафедры философии Национального юридического университета имени Ярослава Мудрого,

г. Харьков, Украина

Жданенко Светлана Борисовна, кандидат философских наук, доцент, доцент кафедры философии Национального юридического университета имени Ярослава Мудрого,

г. Харьков, Украина

Эгерт Владислав Олегович, студент факультета международного права Национального юридического университета имени Ярослава Мудрого, г. Харьков, Украина

\section{ПЕРФОРМАНС В МЕТОДОЛОГИИ ФИЛОСОФИИ ПРАВА}

При помощи перформанса как структурообразующего приема и способа понимающего бытия может быть решена онтологическая проблема присутствия права. Реальность права, которая построена согласно интерактивной модели перформанса, способна не просто открывать свой начальный смысл или получать новый, но и оказывать эффективное воздействие на ее участников, включая их в единый горизонт бытия права.

Ключевые слова: динамизм права, присутствие, перформатив, перформанс, интеракт, телесность права.

\section{$\operatorname{son}$}

